\title{
Kulturowe herbarium. Polityka, etyka i estetyka roślin
}

\author{
[S]tawanie-się-rośliną każe nam myśleć \\ o wielości sposobów, w jakie rośl-inność nas tworzy.
}

Karen Houle, Animal, Vegetable, Mineral

Choć wiemy już, że rośliny zajmują nawet do 99\% biomasy ziemskiej, produktem ubocznym procesów metabolicznych organizmów chlorofilowych jest tlen, a cyrkulacja tlenu i dwutlenku węgla łączy byty auto- $i$ heterotroficzne ludzko-roślinna relacja opiera się na tym nieuniknionym chemicznym współmetabolizmie - to zależności te nie zawsze były (i nadal nie są) oczywiste.

W 1999 roku botanik James H. Wandersee i biolożka Elisabeth E. Schussler zauważyli i nazwali zjawisko ,ślepoty na rośliny” (plant blindness) ${ }^{1}$. Ujmując rzecz skrótowo, polega ono na niedostrzeganiu roślin w ich własnym środowisku, co następnie prowadzi do ignorowania ich znaczenia dla biosfery i człowieka, niedoceniania ich wyjątkowości, a co za tym idzie — uznawania życia roślinnego za mniej wartościowe od zwierzęcego. Rośliny stają się dla człowieka „widzialne", dopiero wtedy gdy współtworzą świat ludzki: są pokarmem, lekiem, trucizną, służą jako materiał budowlany, tkanina lub dekoracja. Źródła ślepoty są zdaniem autorów biologiczne i wiążą się z przystosowaniem gatunkowym do przetrwania w ekosystemie. Bez względu na to, czy ta interpretacja jest słuszna, czy nie, wiele reprezentantek i reprezentantów nauk humanistycznych zadaje pytanie o kulturowe uwarunkowania tej ślepoty. Przyczyną niedostrzegania roślin i ich znaczenia dla istnienia ekosystemu nie jest bowiem niedostatek wiedzy biologicznej, biogeograficznej czy biochemicznej, lecz przede wszystkim określone ideologie i towarzyszące im praktyki bio- i nekropolityczne.

Dostrzegł to Jeffrey Nealon, autor pracy poświęconej teorii roślin, w której proponuje radykalizację myśli biopolitycznej przez włączenie życia roślinnego w jej obręb. Dowodzi, że choć wegetalna zasada (gr. psukhe) życia — nieograni-

1 J.H. Wandersee, E.E. Schussler, Toward a theory of plant blindness, „Plant Science Bulletin” 47, 2001, nr 1, s. 2-9. 
czony wzrost — bardzo dobrze charakteryzuje naszą biopolityczną teraźniejszość (wystarczy chociażby pomyśleć o bioinżynierii kultur tkankowych), to właśnie życie roślinne występuje w roli Innego, niezasługującego na „polityczne rozpoznanie i ochronę"2.

W zachodnim kręgu kulturowym źródeł koncepcji rośliny jako istoty niższej, pośledniej, niemalże nieżywej należy szukać nie tylko w starożytnej filozofii greckiej, lecz także w jeszcze starszych przypowieściach starotestamentowych pochodzących z terenów współczesnej Palestyny. W tradycji judeochrześcijańskiej są one - w momentach kluczowych dla relacji ludu z jego Panem — deprecjonowane. W przypowieści o braciach Kainie i Ablu ofiara tego pierwszego, sporządzona z pieczonych nasion lnu, zostaje odrzucona i uznana za mniej wartościową od tej zwierzęcej, całopalnej, złożonej przez jego brata. W przypowieści o potopie status roślin jako „nieżywych” zostaje jasno określony — w Arce znalazły się „[w]szelkie istoty, w których było tchnienie życia” (Rdz 7, 15) oraz... pasza. Gdy Arka osiadła na suchym lądzie, między Panem a ludźmi zawiązany został akt przymierza; Pan dał ludzkości we władanie wszystko, co się porusza i żyje, przeznaczając to „na pokarm, tak jak rośliny” (Rdz 9, 2-3). Konsekwencją epistemologiczną przymierza jest rozpoznawanie innych istnień (również roślinnych), a także biosystemów (gleba, wody itp.) jako zasobu oraz idące za tym rozpoznaniem prawo własności ziemi, roślin i zwierząt. Użycie, planowanie, kontrola to formy sprawowania władzy; zdominowały one zachodni sposób myślenia o uprawie i hodowli na kolejne tysiąclecia.

Zarówno starożytna, jak i nowożytna filozofia dostrzega u roślin przede wszystkim braki i niedobory w porównaniu do organizmu zwierzęcego. Na niewystępowanie wrażliwości i ruchu (czyli złożoności charakteryzującej organizmy wyższe, zwierzęce) wskazują i Platon, i Arystoteles, co skutkuje lokowaniem duszy roślinnej na najniższym szczeblu drabiny istnień, gdzieś pomiędzy światem nieożywionym a zwierzęciem. Według Arystotelesa trójdzielna dusza ludzka (psukhe to duch, dusza, życie, energia witalna, potencja, moc) składa się z: duszy roślinnej (inaczej wegetalnej lub odżywiającej), charakteryzującej się nieograniczonym wzrostem; duszy zwierzęcej, związanej z odczuwaniem, doświadczaniem i poruszaniem się; oraz duszy ludzkiej, odpowiadającej za myślenie, mówienie i rozumowanie. W konsekwencji większość prac z filozofii przyrody dotyczyła zwierząt; godnym uwagi wyjątkiem jest Teofrast z Eresos, autor dwóch prac poświęconych roślinom. Starożytny podział przetrwał wieki — pojawiał się u Pliniusza, Dioskurydesa, Tomasza z Akwinu. Wraz z końcem tak zwanych ciemnych wieków botaniki (200-1450) niewiele się zmieniło, a oświeceniowy paradygmat mechanizacji materii dodatkowo pogłębił problem „niewidzialności” roślin - istoty wegetalne, poruszające się w sposób niedostrzegalny dla czło-

2 J.T. Nealon, Plant Theory: Biopower and Vegetable Life, Stanford, CA 2016, s. 110. O ile nie podano inaczej, cytaty w przekładzie autorki. 
wieka trudno było traktować jako mechanizm w działaniu. Degradująca życie roślinne hierarchia świata naturalnego wyłoniła się ponownie - nieco odmieniona — w Heideggerowskim trójpodziale na „pozbawiony świata” kamień, „ubogie w świat” zwierzę oraz „wytwarzającego świat” człowieka ${ }^{3}$. Od niemieckiego filozofa nie dowiadujemy się nawet, czy roślina jest „uboga w świat” jak zwierzę, czy też uboższa, pozbawiona świata (bo nieruchoma jak kamień). Choć gwałtownie i bujnie rozrastająca się, roślina jest pozbawiona entelechii i uboga w świat; jest doskonałym przykładem „otwartego”, „,nagiego życia” (Giorgio Agamben ${ }^{4}$ ), niestawiającego oporu, podatnego na manipulację i poddawanie kontroli.

$\mathrm{Z}$ nieobecnością życia roślinnego w zachodniej metafizyce mierzy się filozof Michael Marder ${ }^{5}$, biorąc za sojuszników hermeneutyczną fenomenologię, dekonstrukcjonizm i myśl słabą (il pensiero debole). W swoich pracach szuka sposobów spotkania z rośliną, czyli splątania się dwóch światów lub więcej, bo przecież i rośliny, i ludzie żyją w symbiotycznych relacjach z wieloma organizmami należącymi do różnych królestw. Powołane przez Mardera krytyczne studia nad roślinami (critical plant studies) doczekały się serii wydawniczej pod jego redakcją ${ }^{6}$.

Humanistyczne studia nad roślinami mają jednak swoje początki co najmniej dekadę wcześniej. Już w 2002 roku z perspektywy feministycznej roślinom przyglądała się Elaine P. Miller ${ }^{7}$ — w książce The Vegetative Soul: From Philosophy of Nature to Subjectivity in the Feminine badaczka śledzi zagadnienie podmiotowości roślin w filozofii zachodniej. W tym samym okresie zainteresowanie relacjami ludzi i roślin oraz nie-ludzką sprawczością pojawiło się w obrębie geografii ludzkiej, a już kilka lat później, w 2009 roku, Lesley Head i Jennifer Atchison w artykule Cultural ecology: Emerging human-plant geographies nie tylko dokonali przeglądu dotychczasowych publikacji dotyczących tychże relacji, lecz także proklamowali powstanie nowej dyscypliny — geografii ludzko-roślinnej. Z kolei w 2011 roku Matthew Hall opublikował Plants as Persons: A Philosophical Botany, w której śledzi ujęcia bytu roślinnego w filozofiach, kosmogoniach i teogoniach między innymi europejskiej starożytności, chrześcijaństwa, hinduizmu, buddyzmu i animizmu, zwracając szczególną uwagę na zoocentryzm ujęć zachodnich i proponując stosowanie kategorii osoby (person) w stosunku do istot roślinnych $^{8}$. Rok później (2012) australijski reprezentant studiów kulturowych John Charles Ryan zaproponował powołanie studiów poświęconych relacjom lu-

3 Ibidem, s. 38.

${ }^{4}$ G. Agamben, Homo sacer. Suwerenna władza i nagie życie, przeł. M. Salwa, posł. P. Nowak, Warszawa 2008; idem, Otwarte, przeł. P. Mościcki, „Krytyka Polityczna” 15, 2008, s. 124-138.

5 M. Marder, Plant-Thinking: A Philosophy of Vegetal Life, New York 2013, s. 7.

${ }^{6}$ Wydawnictwo Brill, seria „Critical Plant Studies”, zob. https://brill.com/view/serial/CPST (dostęp: 25.09.2020).

7 E.P. Miller, The Vegetative Soul: From Philosophy of Nature to Subjectivity in the Feminine, Albany-New York 2002, s. 11.

8 M. Hall, Plants as Persons: A Philosophical Botany, Albany-New York 2011. 
dzi i roślin (human-plant studies) $)^{9}$. Również w obszarze antropologii pojawili się badacze przepracowujący tematykę ontologii, epistemologii, a nawet semiotyki roślinnej: przykładowo Eduardo Kohn w How Forests Think: Toward an Anthropology Beyond the Human (2013) studiuje amazoński lud Runa oraz las (selwę), który nie tyle ich otacza, ile żyje i się komunikuje.

Krytyczne studia nad roślinami rozwijają się intensywnie w poprzek dyscyplinarnych i dziedzinowych podziałów. Posthumanistyka przyjmuje założenie o relacyjnym współtworzeniu świata(-ów) dzięki sprawczym splotom tego, co ludzkie i nieludzkie (w tym wegetalne). Postulat stawania się (z) rośliną, zaproponowany już w latach osiemdziesiątych XX wieku przez Gilles'a Deleuze'a i Félixa Guattariego, jest przyjmowany jako model tworzenia i badania wielogatunkowych samopowstających ekosystemów. Co więcej, filozof Emanuele Coccia argumentuje w swojej książce The Life of Plants: A Metaphysics of Mixture ${ }^{10}$, że rośliny tworzą atmosferę czyniącą z wszystkich żyjących istot „miksturę” i włączają je w niekończący się krąg konsumpcji. Takie ekologiczne, a zarazem ucieleśniające ujęcie, wskazujące na ludzko-roślinną korporealność pojawia się nie tylko w filozofii, warto tutaj przywołać chociażby popularnonaukową książkę Michaela Pollana Botany of Desire: A Plant's Eye View of the World (2001), w której śledzi on proces roślinno-ludzkiej koewolucji z perspektywy interesu roślin; pracę Richarda Doyla Darwin's Pharmacy. Sex, Plants, and the Evolution of the Noosphere $(2011)^{11}$, w której autor przedstawia, w jaki sposób rośliny psychoaktywne przyczyniły się do rozwoju noosfery, przestrzeni dyskursywnej mającej zdaniem autora ogromne znaczenie w procesie ewolucyjnym; oraz esej-pamiętnik, czy inaczej „fitobiografię", biolożki Moniki Gagliano Thus Spoke the Plant: A Remarkable Journey of Groundbreaking Scientific Discoveries and Personal Encounters with Plants (2018) ${ }^{12}$, w której autorka opowiada o swoich relacjach z roślinami, komunikacji i rozmowach, w których trakcie rośliny zaprojektowały zakończone sukcesem biologiczne eksperymenty z własnym udziałem ${ }^{13}$.

Istoty wegetalne są również przedmiotem badań i rozważań reprezentantek i reprezentantów studiów wielogatunkowych i postkolonialnych, feministycznego nowego materializmu oraz posthumanistyki filozoficznej. Badaczki posthumanistyczne i nowomaterialistyczne włączają nie-ludzi w obręb rozważań dotyczących

9 J.Ch. Ryan, Passiveflora? Reconsidering nature's agency through human-plant studies (HPS), „Societies” 2, 2012.

10 E. Coccia, The Life of Plants: A Metaphysics of Mixture, [Cambridge-Medford, MA] 2018.

11 R. Doyle, Darwin's Pharmacy. Sex, Plants, and the Evolution of the Noosphere, Washington 2011.

12 M. Gagliano, Thus Spoke the Plant: A Remarkable Journey of Groundbreaking Scientific Discoveries and Personal Encounters with Plants, Berkeley 2018.

13 Dobrym wprowadzeniem w zagadnienia wzajemnych relacji „zjadanych” i „zjadających” jest L. Attala, The "edibility approach": Using edibility to explore relationships, plant agency and the porosity of species' boundaries, „Advances in Anthropology” 7, 2017, $\mathrm{nr}$ 3, s. 125-145. 
sprawczości, odpowiedzialności, wspólnotowości, relacyjności, współwyłaniania się (D. Haraway, A. Tsing, S. Alaimo, C. Sandilands), przyglądają się relacjom ludzi i nie-ludzi w tradycjach indygenicznych, a także powołują się na nienowoczesne epistemologie (R. Kimmerer, D. Bird Rose, T. van Dooren). Krytycznym ujęciom towarzyszą projekty afirmatywne, koncentrujące się na praktykach oporu wobec kapitalistyczno-progresywnej polityki, której podporządkowane są zarówno rośliny, jak i ludzie. Nowe otwarcie na byty wegetalne jest wielokształtne - wyłania się ze studiów postkolonialnych oraz geografii i etnografii nie-ludzkiej. Przedmiotem rozważań i celem praktyk badawczych stają się różne formy ludzko-roślinnego uwikłania: przednowoczesne praktyki żywnościowe, łowiecko-zbieracze, półdzikie systemy ekologiczne, mikrouprawy i permakultura, zbieractwo i ogrodnictwo miejskie, kontrplantacyjne ogrody niewolnicze, ruchy na rzecz rolnictwa tradycyjnego, aktywizm miejski i żywnościowy, zielarstwo, alternatywne farmakopee, rośliny psychoaktywne, ale też sam sposób życia roślin i ich ekologiczne uwikłania. Równocześnie pojawia się coraz więcej prób przepisania na nowo historii botaniki z perspektywy studiów postkolonialnych oraz studiów nad nauką i technologią.

Osiemnastowieczną botanikę Londa Schiebinger określa mianem botaniki pragmatycznej lub stosowanej ${ }^{14}$ — jej celem było stworzenie odpowiedniego systemu klasyfikacji (taksonomii) umożliwiającego uporządkowanie wiedzy przede wszystkim o roślinach mających specyficzne właściwości przydatne gatunkowi ludzkiemu (rośliny lecznicze, barwierskie, włókiennicze, spożywcze czy źródło dóbr luksusowych, perfum i roślin ozdobnych). Wraz z proliferacją handlu zamorskiego w XVI wieku rośliny trafiły do globalnego obiegu towarów — były eksportowane, przesadzane, aklimatyzowane w obcych sobie rejonach, a nawet strefach klimatycznych. Pojawiło się wiele grup „łowców roślin” ${ }^{15}$ — botaników, misjonarzy, kupców oraz innych poszukiwacze przygód i majątków. W koloniach Nowego Świata na niewolniczych plantacjach nie tylko uprawiano rośliny na produkty eksportowe, na przykład cukier, tytoń, przyprawy, barwniki (indygo i koszenilę), żywice i lecznicze kory drzew, lecz także prowadzono naukowe i komercyjne eksperymenty nad możliwością przeszczepu i aklimatyzacji poszczególnych gatunków w nowych siedliskach. Wraz z transferem gatunków miał miejsce globalny transfer wiedzy, jednak — jak wskazuje Schiebinger — w niektórych przypadkach przepływ ten był z różnych politycznych przyczyn blokowany ${ }^{16}$.

Produkcja wiedzy botanicznej była ściśle powiązana z polityką imperialną i ekonomią kolonii (doskonałym przykładem upolityczniania zglobalizowanej botaniki są działania Josepha Banksa), systemy taksonomiczne zaś były uwikłane w ide-

${ }^{14}$ L. Schiebinger, Plants and Empire: Colonial Bioprospecting in the Atlantic World, Cambridge, 2004, s. 6; por. Colonial Botany: Science, Commerce and Politics in the Early Modern World, red. L. Schiebinger, C. Swan, Philadelphia 2005.

15 T. Whittle, Łowcy roślin, przeł. L. Hausbrandtowa, Warszawa 1976.

16 L. Schiebinger, op. cit., s. 153. 
ologie płci i seksualności (wystarczy wspomnieć kontrowersje, jakie początkowo wzbudził system taksonomiczny Carla von Linné, czyli Karola Linneusza) - Patricia Fara mówi nawet o wzajemnym o uwikłaniu „trzech S: płci/seksualności (sex), nauki (science) i państwa (state)" ${ }^{\prime 17}$. W obieg ten włączone były oczywiście akademickie herbaria, a od XVIII wieku - ogrody botaniczne. Rośliny obu Ameryk, interioru afrykańskiego, a później Oceanii i Australii były kolonizowane - zawłaszczane, wywożone, przesiedlane, reaklimatyzowane, a lokalne flory „mieszane” zarówno z importowanymi gatunkami roślinnymi, jak i różnymi mikroorganizmami ${ }^{18}$. Ogromny udział $\mathrm{w}$ tym procederze miały coraz popularniejsze od XVI wieku europejskie ogrody botaniczne, placówki o profilu handlowo-eksperymentalno-naukowo-dydaktyczno-rozrywkowym, spadkobiercy wirydarzy (ogrodów klasztornych), prywatnych lekarskich ogrodów zielnych, a później także miejskich i akademickich. Od XVII wieku szczególnie ważnym ośrodkiem były brytyjskie Królewskie Ogrody Botaniczne ${ }^{19}$. Ich istnienie zasilane było niekończącym się strumieniem kolonialnych „dóbr botanicznych”. Dominowały oczywiście rośliny tropikalne i egzotyczne, ozdobne i użytkowe. Kwitł handel okazami zamorskich roślin, ich nasionami i cebulkami, które w pewnym okresie zyskały status „zielonego złota" 20 — w latach trzydziestych XVII wieku w Niderlandach (Holandii) cebulki tulipanów zarażonych wirusem pstrości tulipana (TBV) - oczywiście ówcześnie nie znano etiologii mozaikowych wybarwień płatków — zyskiwały horrendalne ceny, co prowadziło do powstania rynku spekulacji tym towarem oraz zjawiska społeczno-ekonomicznego określanego mianem „tulipomanii”, a w efekcie do bańki spekulacyjnej oraz bankructwa wielu spekulantów ${ }^{21}$. W kolejnych wiekach zainteresowanie roślinami nie gasło, symbolem osiemnastowiecznego brytyjskiego imperium stała się lilia wodna ${ }^{22}$; w następnym stuleciu powszechne zainteresowanie botaniką nie tylko przyczyniło się do rozwoju nauk przyrodniczych, zaangażowania kobiet $\mathrm{w}$ pracę naukową, ale też infiltrowało publiczne i prywatne sfery życia społecznego, a także spowodowało rozwój romantycznego wyobrażenia o możliwych bliskich relacjach człowieka z przyrodą 23 .

Wiek XVIII to również okres obfitujący w próby przepisania od nowa nauk przyrodniczych oraz stworzenia nowych systemów klasyfikacji organizmów ży-

17 P. Fara, Sex, Botany \& Empire: The Story of Carl Linnaeus and Joseph Banks, London 2003.

18 A.W. Crosby, Imperializm ekologiczny. Biologiczna ekspansja Europy 900-1900, przeł. M. Kowalczuk, Warszawa 1999.

19 L.H. Brockway, Science and Colonial Expansion: The Role of British Royal Botanic Gardens, New York 2002.

20 L. Schiebinger, op. cit., s. 7.

21 A. Goldgar, Tulipmania: Money, Honor, and Knowledge in the Dutch Golden Age, Chicago 2008.

22 P. Gibson, M. Gagliano, The feminist plant: Changing relations with the water lily, „Ethics and the Environment" 22, 2017, nr 2, s. 125-147; T. Holway, The Flower of Empire: An Amazonian Water Lily, The Quest to Make it Bloom, Oxford 2013.

23 T.M. Kelley, Clandestine Marriage: Botany and Romantic Culture, Baltimore 2012. 
wych, z uwzględnieniem zarówno królestwa roślin, jak i zwierzokrzewów (zoophyta). Susannah Gibson uzmysławia czytelnikom swojej książki poświęconej temu zagadnieniu ${ }^{24}$, że nauki przyrodnicze korzystają $\mathrm{z}$ wielu arbitralnie skonstruowanych kategorii i być może również współcześnie obowiązujący paradygmat oparty na teorii komórkowej, naturalnej selekcji, teorii genetycznej i kodzie DNA jest lokalny i historyczny. Kolejne eksperymenty, odkrycia i teorie przyniósł XIX wiek. W studiach nad roślinami coraz częściej pojawia się Charles Darwin, ale nie jako propagator ówcześnie kontrowersyjnej teorii doboru naturalnego, lecz jako badacz świata roślinnego, botanik zafascynowany odkrytym właśnie zjawiskiem fototropizmu, ruchem roślin oraz relacjami, jakie te ostatnie utrzymują z owadami. Również w XIX wieku odkryto chloroplasty, proces fotosyntezy oraz podstawowe prawa dziedziczenia (w efekcie badań Gregora Mendla nad grochem zwyczajnym).

Współczesne nauki o roślinach (plant sciences) potwierdzają pozaeuropejskie i przednowożytne intuicje, że rośliny są aktywnymi, autonomicznymi, odczuwającymi ${ }^{25}$, postrzegającymi organizmami ${ }^{26}$, zdolnymi do komunikacji ${ }^{27}$, złożonych zachowań adaptacyjnych, dbałości o inne organizmy, a także uczącymi się $^{28}$, pamiętającymi i inteligentnymi ${ }^{29}$ formami życia. Reprezentantki i reprezentanci nauk o życiu i nauk humanistycznych coraz częściej współpracują, czego wyrazem mogą być chociażby dwie monografie pod redakcją Moniki Gagliano, Johna Ch. Ryana i Patrícii Vieiry ${ }^{30}$, w których znalazło się miejsce dla perspektyw biologicznej, filozoficznej czy ekokrytycznej. Tak pojmowane byty wegetalne są przedmiotem zainteresowań filozofek i prawniczek proponujących różne ujęcia etyki gatunkowej, zbiorowiskowej, a także ,jednostkowej” roślin (na przykład Christopher D. Stone, Szwajcarski Federalny Komitet ds. Etyki w Zakresie Nie-ludzkiej Biotechnologii, francuskie Zgromadzenie Narodowe, zespół pod kierunkiem Angeli Kalhoff).

24 S. Gibson, Animal, Vegetable, Mineral? How Eighteenth-Century Science Disrupted the Natural Order, Oxford 2015.

25 D. Chamovitz, Zmystowe życie roślin. Co wiedza rośliny, przeł. D. Wójtowicz, Warszawa 2014 [What a Plant Knows: A Field Guide to the Senses, London 2012].

26 S. Mancuso, A. Viola, Błyskotliwa zieleń. Wrażliwość i inteligencja roślin, przeł. A. Wziątek, Wrocław 2013 [Brilliant Green: The Surprising History and Science of Plant Intelligence, Washington 2016].

27 F. Baluška, V. Ninkovi, Plant Communication from an Ecological Perspective, Berlin-Heidelberg 2010.

28 F. Baluška, M. Gagliano, G. Witzany, Memory and Learning in Plants, Berlin-Heidelberg 2018.

29 A.J. Trewavas, Plant Behaviour and Intelligence, Oxford 2015.

30 P. Vieira, M. Gagliano, J.Ch. Ryan, The Green Thread: Dialogues with the Vegetal World, [b.m.w.] 2015; M. Gagliano, J.Ch. Ryan, P. Vieira, The Language of Plants: Science, Philosophy, Literature, Minneapolis, MN 2017. 
Kolejnym bardzo ważnym przedmiotem zainteresowań współczesnych humanistycznych studiów nad roślinami są bio- i nekropolityczne praktyki podporządkowywania bytów roślinnych charakteryzujące nowożytną gospodarkę rolną. Przemysłowe uprawy, hodowle i leśnictwo podporządkowane są technonaukowym procedurom; wytwarzają areał i biomasę w miejsce ekosystemów i organizmów roślinnych. Współczesne monokulturowe uprawy i wielohektarowe farmy są spuścizną kolonialnych plantacji. W plantacjocenie ${ }^{31}$ uprawy, pastwiska i lasy zostały przekształcone w plantacje, których funkcjonowanie i produktywność często wymagają zniewolonej, nisko opłacanej siły roboczej. Praktyki zainicjowane w XV wieku przez hiszpańskich i portugalskich kolonizatorów i rozwijane w kolejnych wiekach na plantacjach niewolniczych były modelem seryjnego przemysłowego zarządzania kolejno fabryką, hodowlą i w końcu uprawą ${ }^{32}$. Monokultura oraz chemiczne i biotechnologiczne ingerencje umożliwiające wytworzenie i utrzymanie tak niekorzystnego życiowo środowiska stały się w XXI wieku standardem. Poszukiwania idealnej rośliny uprawnej wiązały się z wynajdywaniem nowych norm, które z kolei wpływały (i wpływają) na kształt ówczesnego (i współczesnego) rolnictwa. Agrarny ,typ idealny” można zestawić tu z ideą prarośliny (Urpflanze) towarzyszącą filozoficzno-botanicznym poszukiwaniom prowadzonym na przełomie XVIII i XIX wieku przez niemieckiego filozofa Johanna Wolfganga von Goethego, nie przypadkiem też pomysł idealnej rośliny uprawnej ponownie wybrzmiał w polityce rolnej Trzeciej Rzeszy — zainicjowano wówczas intensywne poszukiwania „czystych” odmian różnych roślin spożywczych ${ }^{33}$.

Praktyki normatywizacji i standaryzacji życia roślinnego są sednem wykorzystywanej w rolnictwie inżynierii genetycznej, służącej wytwarzaniu kolejnych „doskonałych” - odpornych na warunki środowiskowe i mających wysoką wartość odżywczą — odmian roślin. Co więcej, praktykom tym towarzyszy biopiractwo oparte między innymi na zawłaszczaniu i prywatyzacji kodu DNA wypreparowanych gatunków ${ }^{34}$. Problematyka własności dotyczy nie tylko samego kodu życia, lecz także nasion. Próba zabezpieczenia wzorca genetycznego poszczególnych roślin - w formie fizycznej i cyfrowej - będąca wyrazem troski o przyszłość żywieniową planety, przejawia się w dyskursie i praktyce tworzenia banków nasion (oraz banków genów), choć oczywiście docelowo bank ma za zadanie chronić nie ciała roślinne, a ludzkie ${ }^{35}$. Niemiecka filozofka i biolożka Nicole Karafyllis przypomina za Arystotelesem, że „[n]asiono i jego medium po-

31 D. Haraway et al., Anthropologists are talking - about the anthropocene, „Ethnos” 81, 2016, nr 3, s. 535-564.

32 S.W. Mintz, Sweetness and Power: The Place of Sugar in Modern History, New York 1986.

33 T. Wieland, Autarky and Lebensraum. The political agenda of academic plant breeding in Nazi Germany, „Journal of History of Science and Technology” 3, 2009, s. 14-34.

34 V. Shiva, Biopiracy: The Plunder of Nature and Knowledge, Boston 1997.

35 S. Haylie, The Secret Lives of Dead Plants, 50th International Congress on Medieval Studies, Medieval Institute, College of Arts and Sciences, Western Michigan University, Kalamazoo 2015. 
społu są substancją (po grecku ousía) stawania się"36. Zachowanie roślin wymaga zachowania nie tylko materiału genetycznego danego gatunku, ale całej sieci relacji, z którą i w obrębie której rośliny stają się — ziemi, mikroorganizmów, owadów. Chronione w bankach rośliny przemieniane są w biofakty, które „rosną” tylko dzięki zastosowanym procedurom i metodom, technologii i genetyce ${ }^{37}$; współczesna biotechnologia i biobanki tworzą „epistemiczno-moralne hybrydy”, zamieniając ,żyjące rzeczy” w zasoby (stocks), opcje i aktywa ${ }^{38}$.

Wraz z nowożytnym (nadpisanym nad filozoficznymi ujęciami życia roślinnego jako nie-życia) procesem wikłania życia roślinnego w praktyki ekonomiczne oraz podporządkowaniem zachodnich nauk poświęconych roślinom (botaniki, ale też biologii, farmacji, medycyny) wymogom rynku nastąpiła intensyfikacja interwencji biopolitycznych - normatywizacja i zarządzanie dotyczą samego życia (to jest zarówno kodu genetycznego, jak i ,nieosobniczych” kultur tkankowych).

Troska o wspólnie tworzony świat (lub może raczej wspólnie tworzone światy) rodzi pytania o to, jak być, działać i stawać się z roślinami. To, jak osoby „,zaangażowane w rośliny” (teoretyczki, filozofki, biolożki, rolniczki, artystki i oczywiście nie tylko) definiują — implicytnie i eksplicytnie — życie roślinne, kształtuje ramy etyczne ich działań, wpływa na to, jak odnoszą się do ciał roślinnych. Współczesne artystki i artyści w zupełnie inny sposób niż wcześniej pracują z roślinami; inne zagadnienia pojawiają się w dyskursie estetyki roślin. Za Johnem Ch. Ryanem można wskazać tradycyjne formy sztuki roślin: sztukę wizualną (tworzenie reprezentacji roślin, ilustracje botaniczne, martwe natury), sztukę taktylną (wykorzystanie materiału o roślinnym pochodzeniu, na przykład drewna lub liści) oraz rośliny będące obiektami artystycznymi (jak kompozycje ogrodowe). Sztuka-roślin (zapisywana z łącznikiem) obejmuje spektrum działań artystycznych angażujących żywe rośliny, w tym z jednej strony sztukę instalacji oraz performansu i choreografii, a z drugiej - działania wymagające mediacji technologicznej — sztukę interfejsu, mediów wilgotnych czy sztukę biologiczną (bio art). W swoich praktykach artystki próbują przekroczyć ograniczenia wynikające z fragmentującej, uniwersalizującej i homogenizującej świat nowoczesnej perspektywy, próbują odnowić „kontrakt roślinny”, jak ich agendę określa Prudence Gibson ${ }^{39}$. Roślinami w sztuce zajmuje się coraz większa grupa badaczek i krytyczek, a historyk sztuki Giovanni Aloi nie tylko jest redaktorem monografii poświęconych roślinom w sztuce ${ }^{40}$, lecz także stymuluje rozwój dyskursu we-

${ }^{36}$ N. Karafyllis, "Hey plants. Take a walk on the wild side!": The ethics of seeds and seed banks, [w:] Plant Ethics: Concepts and Applications, red. A. Kallhoff, M. Di Paola, M. Schörgenhumer, Abingdon-New York 2018, s. 198.

37 Ibidem, s. 194.

38 Ibidem, s. 200.

39 P. Gibson, The Plant Contract: Art's Return to Vegetal Life, Boston 2018.

40 Botanical Speculations: Plants In Contemporary Art, red. G. Aloi, Newcastle upon Tyne 2018; Why Look at Plants?: The Botanical Emergence in Contemporary Art, red. G. Aloi, Boston 2018. 
getalnego na łamach redagowanego przez siebie pisma „Antennae, The Journal of Nature and Visual Culture" 41 . Wiele na temat roślin w bio arcie, a szerzej w sztuce, napisała polska filozofka Monika Bakke. Co więcej, roślinom oraz ich związkom z ludźmi coraz częściej poświęca się czas i miejsce nie tyle w muzeach przyrodniczych, ile w galeriach sztuki i innych przestrzeniach kulturalnych.

Należy podkreślić, że wskazane zagadnienia oczywiście goszczą już w polskim dyskursie akademickim, są jednak bardzo rozproszone. Jeśli chodzi o publikacje skupiające się na humanistycznych studiach nad roślinami, przede wszystkim chciałabym zwrócić uwagę na dwa numery pisma „Czas Kultury”: poświęcony rośl-inności (nr 5 za 2008 rok) oraz lasowi (nr 3 za 2017 rok); również w ekokrytycznym numerze „Tekstów Drugich” (nr 2 za 2018 rok) można znaleźć kilka ważnych tekstów na temat roślin.

$$
* * *
$$

Poświęcenie tomu „Prac Kulturoznawczych” istotom wegetalnym właśnie teraz — w 2020 roku — jest znaczącym gestem, gdyż Organizacja Narodów Zjednoczonych ustanowiła go Międzynarodowym Rokiem Zdrowia Roślin (rezolucja ONZ nr 73/252). Zdrowie roślin, jak stwierdzono w rezolucji, jest zagrożone między innymi przez ,wprowadzenie organizmów szkodliwych na nowe terytoria, poprzez intensywny wzrost międzynarodowego obrotu towarami roślinnymi i postępujące zmiany klimatyczne"42. Jak wiemy, ludzko-roślinne uwikłania są często po prostu niewidzialne, a co więcej w interesie ponadnarodowych korporacji (również żywieniowych, farmaceutycznych i technologicznych) i globalnych inwestorów często leży odwracanie uwagi społeczeństwa zarówno od prekarności samego życia roślinnego, jak i oczywistych ekosystemowych i wielogatunkowych zależności. Dlatego tak ważne jest podejmowanie tej tematyki nie tylko przez reprezentantki i reprezentantów nauk o życiu, lecz także te i tych działających na polu humanistyki środowiskowej i sztuki.

Przedstawione we wstępie tropy były punktem wyjścia dla autorek i autorów tomu Kulturowe herbarium, podejmujących rozważania na temat (bio)polityki, etyki i estetyki roślin. W tomie prezentowane są tłumaczenia dwóch istotnych dla kulturowych studiów nad roślinami tekstów oraz sześć artykułów problemowych polskich autorek i autorów.

Sylvie Pouteau, biolożka i filozofka, w artykule Rośliny jako istoty otwarte. Od estetyki do etyki roślinno-ludzkiej zastanawia się, jakie nowoczesne bariery koncepcyjne uniemożliwiają człowiekowi dostrzeżenie, że ośrodki wartości mogą być ulokowane poza istotami zwierzęcymi (w tym ludźmi), a także utrudniają rozważenie możliwości lub wręcz konieczności wypracowania etyki roślinno-ludzkiej. Według

\footnotetext{
${ }^{41} \mathrm{http}: / / w w w . a n t e n n a e . o r g . u k /(d o s t e ̨ p: ~ 25.09 .2020)$.

42 https://www.rokroslin.pl/informacje (dostęp: 28.09.2020).
} 
autorki zasadnicza trudność etyki roślinnej wynika z naszego wyobrażenia, czym są rośliny, oraz ze sposobu, w jaki nowoczesna umysłowość ujmuje kwestie etyczne. Dlatego Pouteau przybliża czytelniczkom i czytelnikom, czym (lub kim) w rzeczywistości są rośliny, rozpoczynając od estetycznej analizy morfologii roślinnej.

Zagadnienia estetyki i etyki roślin podejmują Mateusz Salwa w tekście Piękny okaz. Roślina jako dzieto sztuki oraz Magdalena Zamorska w artykule Etyka roślin. Wiedza, troska i stawanie się z Innymi. Catriona Sandilands, socjolożka pracująca w obrębie humanistyki środowiskowej oraz studiów genderowych, w pracy Botaniczne sensacje. Biopolityka roślinna kreśli sposoby, w jakie rośliny zostają wplecione we współczesną biopolitykę. Rośliny są tu postrzegane raczej jako sprawcze podmioty o specyficznych właściwościach, na wiele sposobów uwikłane we współoddziaływania społeczno-polityczne, niż bierne przedmioty podległe działaniom innych. Co więcej, istoty wegetalne gmatwają problematykę życia jako takiego. Dlatego też, przyjmując etyczne i polityczne stanowisko wobec życia roślinnego, musimy wykroczyć poza proste stwierdzenie podobieństwa roślin do ludzi i uznać również ich nieusuwalne różnice. Zagadnienie możliwych sposobów bycia i stawania się z roślinami podejmowane są z bardzo różnych perspektyw w czterech artykułach: Manna Polonicum. Szkic fitokulturoznawczy Tomasza Majewskiego, Społeczne uchwastowienie. W poszukiwaniu sposobów bycia z odrzuconymi Aleksandry Brylskiej, BIOgrafia mandragory - o korporalności kobiety-rośliny Moniki Sadowskiej oraz Komunikacja na liniach biofeedbacku - zwiazki sound artu z eksperymentami sonifikującymi rośliny Justyny Stasiowskiej. Autorki i autor pytają o to, jak ludzko-roślinne sploty kształtowały się w obrębie praktyk codziennych i artystycznych.

Tytułując tom Kulturowe herbarium, zastanawiałam się nad tym, czym jest herbarium, zielnik. Myślałam o różnych jego formach, zarówno o ogromnych zbiorach spreparowanych roślin, przechowywanych w szczelnie zamykanych metalowych szafach, jak i cienkich notesach, do których wklejałam ,suszki”, będąc dzieckiem; o pożółkłych księgach wypełnionych fantazyjnymi rycinami i o wirtualnych herbariach, udostępniających nie tylko zcyfryzowane historyczne materiały, lecz także nowe obrazy wytwarzane za pomocą zaawansowanych technologii. Postrzeganie roślin oraz określone możliwości stawania się wraz z nimi są warunkowane zarówno dostępnymi narzędziami i technologiami, jak i ideologiami oraz paradygmatami poznawczymi. Mam nadzieję, że stworzone przez autorki i autorów tego tomu kulturowe herbarium będzie kolejnym ważnym ziarnem kiełkującym na polu współczesnych studiów nad roślinami. 


\section{Bibliografia}

Agamben G., Homo sacer. Suwerenna władza i nagie życie, przeł. M. Salwa, posł. P. Nowak, Warszawa 2008.

Agamben G., Otwarte, przeł. P. Mościcki, „Krytyka Polityczna” 15, 2008, s. 124-138.

Attala L., The "edibility approach": Using edibility to explore relationships, plant agency and the porosity of species'boundaries, „Advances in Anthropology” 7, 2017, nr 3, s. 125-145.

Baluška F., Gagliano M., Witzany G., Memory and Learning in Plants, Berlin-Heidelberg 2018.

Baluška F., Ninkovič V., Plant Communication from an Ecological Perspective, Berlin-Heidelberg 2010.

Botanical Speculations: Plants in Contemporary Art, red. G. Aloi, Newcastle upon Tyne 2018.

Brockway L.H., Science and Colonial Expansion: The Role of British Royal Botanic Gardens, New York 2002.

Chamovitz D., Zmystowe życie roślin. Co wiedza rośliny, przeł. D. Wójtowicz, Warszawa 2014 [What a Plant Knows: A Field Guide to the Senses, London 2012].

Coccia E., The Life of Plants: A Metaphysics of Mixture, [Cambridge-Medford, MA] 2018.

Colonial Botany: Science, Commerce and Politics in the Early Modern World, red. L. Schiebinger, C. Swan, Philadelphia 2005.

Crosby A.W., Imperializm ekologiczny. Biologiczna ekspansja Europy 900-1900, przeł. M. Kowalczuk, Warszawa 1999.

Doyle R., Darwin's Pharmacy. Sex, Plants, and the Evolution of the Noosphere, Washington 2011.

Fara P., Sex, Botany \& Empire: The Story of Carl Linnaeus and Joseph Banks, London 2003.

Gagliano M., Thus Spoke the Plant: A Remarkable Journey of Groundbreaking Scientific Discoveries and Personal Encounters with Plants, Berkeley 2018.

Gagliano M., Ryan J.Ch., Vieira P., The Language of Plants: Science, Philosophy, Literature, Minneapolis, MN 2017.

Gibson P., The Plant Contract: Art's Return to Vegetal Life, Boston 2018.

Gibson P., Gagliano M., The feminist plant: Changing relations with the water lily, „Ethics and the Environment" 22, 2017, nr 2, s. 125-147.

Gibson S., Animal, Vegetable, Mineral? How Eighteenth-Century Science Disrupted the Natural Order, Oxford 2015.

Goldgar A., Tulipmania: Money, Honor, and Knowledge in the Dutch Golden Age, Chicago 2008.

Hall M., Plants as Persons: A Philosophical Botany, Albany-New York 2011.

Haraway D., Ishikawa N., Gilbert S.F., Olwig K., Tsing A.L., Bubandt N., Anthropologists are talking - about the anthropocene, „Ethnos” 81, 2016, nr 3, s. 535-564, DOI: 10.1080/00141844. 2015.1105838.

Haylie S., The Secret Lives of Dead Plants, 50th International Congress on Medieval Studies, Medieval Institute, College of Arts and Sciences, Western Michigan University, Kalamazoo 2015.

Holway T., The Flower of Empire: An Amazonian Water Lily, The Quest to Make it Bloom, Oxford 2013.

Houle K., Animal, vegetable, mineral: Ethics as extension or becoming? The case of becoming-plant, „Journal for Critical Animal Studies” 9, 2011, nr 1-2, s. 89-116.

Karafyllis N., "Hey plants. Take a walk on the wild side!": The ethics of seeds and seed banks, [w:] Plant Ethics: Concepts and Applications, red. A. Kallhoff, M. Di Paola, M. Schörgenhumer, Abingdon-New York 2018.

Kelley T.M., Clandestine Marriage: Botany and Romantic Culture, Baltimore 2012.

Mancuso S., Viola A., Błyskotliwa zieleń. Wrażliwość i inteligencja roślin, przeł. A. Wziątek, Wrocław 2013 [Brilliant Green: The Surprising History and Science of Plant Intelligence, Washington 2016]. 
Marder M., Plant-Thinking: A Philosophy of Vegetal Life, New York 2013.

Miller E.P., The Vegetative Soul: From Philosophy of Nature to Subjectivity in the Feminine, Albany-New York 2002.

Mintz S.W., Sweetness and Power: The Place of Sugar in Modern History, New York 1986.

Nealon J.T., Plant Theory: Biopower and Vegetable Life, Stanford, CA 2016.

Ryan J.Ch., Passive flora? Reconsidering nature's agency through human-plant studies (HPS), „Societies" 2, 2012, s. 101-121.

Schiebinger L., Plants and Empire: Colonial Bioprospecting in the Atlantic World, Cambridge 2004.

Shiva V., Biopiracy: The Plunder of Nature and Knowledge, Boston 1997.

Trewavas A.J., Plant Behaviour and Intelligence, Oxford 2015.

Vieira P., Gagliano M., Ryan J.Ch., The Green Thread: Dialogues with the Vegetal World, [b.m.w.] 2015.

Wandersee J.H., Schussler E.E., Toward a theory of plant blindness, „Plant Science Bulletin” 47, 2001, nr 1, s. 2-9.

Whittle T., Łowcy roślin, przeł. L. Hausbrandtowa, Warszawa 1976.

Why Look at Plants?: The Botanical Emergence in Contemporary Art, red. G. Aloi, Boston 2018.

Wieland T., Autarky and Lebensraum. The political agenda of academic plant breeding in Nazi Germany, „Journal of History of Science and Technology” 3, 2009, s. 14-34. 